\title{
OVERVIEW OF FINANCIAL TECHNOLOGY (FINTECH) IN LOGISTICS: LITERATURE STUDY
}

\author{
* Muhammad Arif Hernawan', Cecep Pahrudin ${ }^{2}$, Muhammad Rifa Affiat ${ }^{3}$, Siti Nurhayati $^{4}$ \\ 1,2,3,4 Institut Transportasi dan Logistik Trisakti, Jakarta, Indonesia \\ *Coresponding author. \\ E-mail addresses: arifhernawan1112@gmail.com
}

\section{ARTICLE INFO \\ Article history: \\ Received: \\ 3 March 2021 \\ Accepted: \\ 15 April 2021 \\ Available online: 4 Mei 2021}

\begin{abstract}
The purpose of this research is to provide insights into existing literature from various sources that can be combined with the reality of existing scientific articles. The research ideas and results in this research paper also outline variables that can be used for further research, such as data protection, financial technology, logistics, and government policies. Of the 3 descriptions withinside the effects and dialogue above, there are 3 variables that may make destiny studies substances or references, specifically financial era that has been used with customer confidentiality this is nonetheless now no longer maximally maintained, secondly there is a central authority coverage that truly covers this economic era in order that it may be used, supervised via way of means of the government. Third, there are not many logistics corporations that use economic era as a method of price to consumers, there are numerous obstacles, from control selections and help that can be facilitated with the aid of using the authorities with the lifestyles of present Financial Technology Institutions with cooperation. This qualitative study remains some distance from perfect, and simplest as an overview cloth from researchers and as a contribution to the improvement of science, mainly withinside the area of virtual finance, and logistics in general. The studies effects of this text can offer idea blessings for technology for the ones in need.
\end{abstract}

Keyword: Financial Technology (Fintech), Logistics, Confidentiality and Regulation

\section{INTRODUCTION}

The use of era cannot be denied and cannot be prevented in diverse or fields of existence in society in general, using era in all elements of existence is visible, in facilitating the distribution and transport of products ordered with the aid of using the public. This makes era in monetary services, or higher called Financial Technology, to be utilized by the logistics quarter. Electronic trade has damaged thru the limits of conventional business. The lifestyles of digital markets, stores that do not occupy any bodily space, permitting get entry to and flow to those markets to be performed every time and everywhere withinside the world, without leaving the house is an everyday aspect we do today. Select and order gadgets which can be in digital save home windows from different elements of the arena and promote it on digital networks and price is supplied thru on-line services, all those alternatives have caused on-line trade being taken into consideration the miracle of the century (Gandara, 2018). Every agency presently makes use of the net as an era that allows in bills till items arrive to consumers (Susilo et al., 2019). No era, no finance (Mao et al., 2019) 
Countries in Southeast Asia presently have a populace of about six hundred million people, round 250 million of whom are in Indonesia, with a hugely growing net access, accompanied with the aid of using an excessive penetration of phone sales, making the Southeast Asia location a capacity e-market. trade and the usage of economic generation in assisting big logistics. In the felony aspect, Indonesia presently has a felony device that regulates digital transactions, specifically Law No. eleven of 2008 regarding the Law on Information and Electronic Transactions (UU-ITE), which includes, amongst different things, regulating efforts to guard the public from digital transactions. In addition, Indonesia additionally has Law no. 7 of 2014 which particularly regulates digital trade. According to Law Number 7 of 2014, Business Actors in digital trade are declared obliged to check in and observe the technical provisions of the applicable agencies. Every enterprise actor must have and claim enterprise ethics (enterprise behavior or code of practices). Business actors are prohibited from requiring purchasers to pay for merchandise despatched without previous agreement (inertia selling). Electronic records or files may be used as evidence.

Electronic records or files have the identical felony pressure as a genuine deed. Regarding digital contracts, digital buying and selling contracts are legitimate whilst there may be a settlement among the parties. Electronic buying and selling contracts should as a minimum comprise the identification of the parties, specs for items and or offerings agreed upon, legality of products and or offerings, cost of alternate transactions, phrases and phrases of price, operational methods for shipping of products and or offerings, and methods for returning items and / or if there may be a mismatch. In the occasion of a dispute associated with alternate transactions via a digital gadget, the man or woman or enterprise entity experiencing a dispute can solve the dispute via a courtroom docket or via different dispute decision mechanisms. (Maulana, 2018). Furthermore, consistent with Law Number 7 of 2014, each enterprise actor who trades items and / or offerings the use of a digital gadget is needed to offer whole and accurate facts and / or records (1). Every Business Actor is illegitimate from buying and selling items and / or offerings the use of a digital gadget this is inconsistent with facts and / or records (2). The use of digital structures should follow the provisions stipulated withinside the Law on Electronic Information and Transactions (3). Data and / or records as a minimum contains: identification and legality of Business Actor as manufacturer or Distribution Business Actor (a); Technical necessities of the Goods offered (b); technical necessities or qualifications of the Services offered (c); costs and price strategies for items and / or offerings (d); and the technique of shipping of products (e). Every Doer Businesses that alternate items and / or offerings the use of digital structures that do not offer whole and accurate facts and / or records could be situation to administrative sanctions withinside the shape of license revocation. Every Business Actor who trades items and / or offerings the use of a digital gadget this is incompatible with the facts and / or records as noted in Article sixty-five paragraph (2) (The use of digital structures should follow the provisions stipulated withinside the Electronic Information and Transactions Law) will be sentenced to imprisonment of as much as 12 (twelve) years and / or a most first-rate of Rp. 12,000,000,000.00 (twelve billion rupiah). Problems continue to be that if resolved should make virtual finance paintings higher for individuals, corporations, and governments. (Ozili \& Outa, 2017). The virtual economic system in Asian international locations includes revamping enterprise methods via technological innovation, coverage governance for growth, and virtual entrepreneurship (Li et al., 2020). Making a platform to aid the Logistics Business has now been carried out and makes use of economic generation financing, it is simply that the supervision of the lifestyles of Financial Technology has now no longer been maximal. The lifestyles of ease of price withinside the cutting-edge logistics area does now no longer save you violations, there may be nevertheless a loss of safety for customer facts that may offer a feel of safety in transactions on this logistics area. (Damuri et al., 2021)

Bain \& Company said that the contribution of the virtual enterprise in Indonesia reached USD forty-four billion in 2020. In fact, this contribution is anticipated to retain to boom to attain USD 124 billion in 2025. BPS (2019) withinside the census unfolds throughout one hundred and one districts / towns in Indonesia recorded most effective $15.08 \%$ of corporations use e-trade as their income platform. There are nevertheless many enterprise actors on online platforms, specifically in assisting facilitate transactions through the usage of economic era withinside the trial and blunders level or now no longer making buying and selling sports in etrade their primary activity. Thus, the turnover of enterprise actors will nevertheless be very excessive and could most effectively turn out to be an impediment if anybody wishes to attend to permits.

Flexibility is likewise wanted for customers of monetary era withinside the area of logistics, further, to ease of taxation and different obligations. The procedure of logistics in securities transactions implies a stability among procedure design, stakeholder perceptions of chance and trust. (Toppen et al., 1998). 


\section{LITERATURE REVIEW}

Fintech is an acronym of Financial Technology that describes an agency or a subsidiary that mixes a monetary carrier with technology. Every agency insisted to be labelled as fintech must provide Internet-primarily based totally merchandise with and applications (apps) established in system or smartphone. Generally, those modernized organization's goal to draw the hobby of customers with merchandise, easy-to-use services, efficiency, and transparency in comparison to the traditional business.

Fintech might not be categorised primarily based totally on its use in authority's guidelines or prison documents. Fintech agencies follow sure forms of prison duties and unique regulations due to their sort of enterprise. The distinction in enterprise is that services and products provide many things (Susilo et al., 2019). There are essential elements riding the evolution in economic generation innovation, namely (Bernanke \& others, 2009); (Awrey, 2013); (De Haan et al., 2020); (Board, 2017b); and (Board, 2017a): the energy of call for (call for aspect) and the energy of supply (supply). aspect). Factors originating from the call for aspect include: First, moving purchaser alternatives that influence purchaser call for innovation. Easy net get admission to and the cap potential of net community customers to transact real-time have pushed excessive expectations, specifically concerning convenience, speed, decrease costs, and simplicity of use of offerings, finance. In addition, adjustments in alternatives additionally arise because of the affect of demographic elements that force call for, which includes accelerated attractiveness from businesses that do develop with virtual generation (virtual natives) and millennials. Second, technological evolution. Technological innovation in economic offerings is growing swiftly and in new methods and taking gain of various enterprise models.

Mobile price is a price technique for services and products which use devices including cell phone or PDA. This form of price pertains to the price gadget the usage of cell credit and additionally the devices to speak with the person route via way of means of using the wi-fi technology (Rahayu et al., 2014). Mobile price offers positive to users, including its sensible utilization and smooth get entry to so long as the sign is present (Fontes et al., 2017).

Start-ups also are covered withinside the sort of Small and Medium Enterprises (SMEs) or Micro, Small and Medium Enterprises (MSMEs), however the traits of Start-up are shifting withinside the fields of technology, websites, and topics associated with the internet. Every man or woman or start up that earns earnings from items buying and selling enterprise or provider management, should be taxed. Government policies associated with earnings tax on begin ups are the issuance of Government Regulation No. 46 of 2013 that is powerful as of one July 2013 and known as Final Income Tax).

The Final Income Tax is imposed primarily based totally on attention of the want for simplicity in tax collection, decreased administrative burden for each Taxpayers and the Directorate General of Taxes, and considering monetary and economic conditions. In its efforts to inspire the success of voluntary tax responsibilities and inspire the contribution of nation sales from Start-ups, the Government issued Government Regulation No. 23 of 2018 which changed Government Regulation No. forty six of 2013. With this authorities' regulation, taxpayers who've a gross flow of commercial enterprise as much as 4. eight billion Rupiah can also additionally now not calculate taxes at a price of $1 \%$ however makes use of a $0.5 \%$ tariff scheme. (Supardianto et al., 2019).

Digital transformation is a level of making use of facts technology. Digital transformation also can be described as an idea of digitizing or lowering paper use (paperless) of the enterprise of individuals (Patel \& McCarthy, 2000). Focus on virtual transformation in numerous parts, particularly centralization, statistics, and automation. Digital transformation enables tax compliance and facilitates deal with tax risks, via multiplied best, stronger value, more transparency, and decrease costs. Improving statistics governance, statistics management, and best is likewise vital to evaluate gaps and duality troubles in cutting-edge statistics sources (Hadzhieva, 2019). Several answers may be selected as virtual software answers to accounting governance; particularly; Paperless accounting, Interfaces to an outside system, Management of statistics best, Process automation, Uniform of systems, Integrated consolidation system, Real-time reporting, Creation of transparency, big statistics analyses, Tools for visualization, and Cloud computing (Kreher et al., 2017).

(Tsing, 2016) coined the period deliver chain capitalism to explain an ancient configuration of capitalism wherein groups produce and distribute items globally. She stresses the numerous dis- persed and choppy relationships and situation positions - in phrases of nationality, ethnicity, class, gender etc. - related alongside an unmarried deliver chain. Supply chains gather a complexly entangled and un- even collective alongside its path, which is, maximum of the time, now no longer even aware about itself. Connecting with Tsing's evaluation we need to factor out that this "political economic system of articulated heterogeneity" (Tsing, 2016) essentially 
rests on numerous technological and calculative revolutions in managerial logistics all through the second one $1 / 2$ of the twentieth century (Allen \& Garlan, 1997); (Cowen, 2014); (Danyluk, 2018). Moving items or the commercial enterprise of promoting the relocation of factors in space (Marx, 1963) became for hundreds of years idea of as an appendix to manufacturing. This modified withinside the 1960s, while predominant groups enthusiastically followed insights from World War II operations studies. The operational angle allowed transportation to be taken into consideration as a quintessential a part of the manufacturing process (Bielawski, 1971). The cloth flow, which had formerly existed withinside the shadows as a set fee after pro- duction, now have become a phenomenon subjected to extreme scrutiny. Moving shipment represents handiest one operation of contemporary-day logistics ((Meyer \& Allen, 1997). What makes up contemporary-day logistics is its function as an interface that connects the specific operations of producing and distribution into a "community of non-stop manufacturing" (Cowen, 2014). This improvement additionally stems at once from encounters among navy operations studies and the technological know-how of logistics. A device derived from operations studies, the full fee evaluation, recalibrated the logistics enterprise with lasting effects (Cowen, 2014). The statistics sheets of general fee calculation allowed a mass of grounded statistics at the rate and availability of uncooked materials, the rate of human labor, and tax regimes to be assembled in the sort of manner as to optimize income at each stage.

This highbrow recalibration of logistics as the "key operational field of a globalizing economy" (Holmes, 2011) co-advanced with extensively followed socio-technical requirements and an infrastructural overhaul on a worldwide scale. The standardization of shipping mediums, regularly in direct relation to army campaigns which include in Vietnam (Levinson, 2006), cleared a manner for a brand-new temporal rhythm of on de- mand manufacturing and delivery (Holmes, 2011). To conquer the disproportion among deliver and call for, Japanese automobile producers advanced a gadget of just-in-time manufacturing, which rearranged the enterprise of procurement decisively. In evaluation to inventory, inventory sitting idle in a warehouse (in a "jail of price", to speak - (Danyluk, 2018), factories and distribution facilities started out to get hold of cloth flows which will ahead them to their subsequent destination, both at once and after similarly processing. From the 1980s, this new time horizon created a brand-new call for to control the connectivity of person chains of price introduction alongside the unequal geographies of the arena market. Drawing on insights from operations research, the sphere of deliver chain control took over as a brand-new governance method that encompassed the complete association of logistics, concerning all "channel partners" which include "suppliers, intermediaries, 0.33 celebration provider providers, and customers" (Vitasek, 2013).

This shift closer to flow created efficiencies for the operations of transnational corporations and safeguarded their returns on investments. At the identical time, the brand-new circuits of logistics additionally fabricated a brand-new transversal trouble area. As Deborah Cowen stresses, "if the deliver chain stretches the manufacturing facility throughout the corridors, nodes, and seams of logistics area, it's far a device this is extraordinarily prone to disruption" (Cowen, 2014). In this context, professionals including the World Eco- nomic Forum's head of Supply Chain and Transport Industry segment kingdom that, "[t]he international threat society is reality. [...] This additionally influences the deliver chain" ((Lehmacher, 2015), authors' transl.). Sharing conspicuous similarities with (Beck, 2002) analysis of an international threat society, professionals well known that the skeleton of logistics can also additionally unleash "unknown and accidental consequences" but is on the identical time a "critical device" (Collier \& Lakoff, 2015). While pupils have taken up the reframing of logistics withinside the con- textual content of country wide protection and the controversies among the suitable of territorial integrity and the securitization of flows (Cowen, 2010); (Opitz \& Tellmann, 2012); (Salter, 2013), Supply Chain Security (SCS) as a company praxis has but to acquire greater attention. Logistics has turn out to be a debatable trouble area withinside the wake of fundamental disruptive occasions in current years. Weeks after the Great East Japan earthquake, the complicated entanglements of world deliver have become seen while international manufacturing enterprise skilled the aftershocks of the disaster. The earthquake and the following tsunami destroyed many production flowers throughout Japan. This caused an excessive international deliver scarcity of key components and prompted economic losses. As The Economist (2011) wrote withinside the aftermath of the catastrophe, "simply as a few economic establishments proved 'too massive to fail', a few Japanese providers are actually discovered to be too (Folkers \& Stenmanns, 2019) essential to do without." After the earthquake, protection professionals emphasized the want for a greater thorough implementation of requirements including the ISO 28000, which prescribes, among different things, the identification of all stakeholders in a deliver chain, consisting of individuals who are simplest in an indirect, mediated courting to a chain.

Financial capitalism is in lots of approaches associated with the arena of logistics. Supply chain capitalism relies upon on finance (Tsing, 2009) as it equips buyers with capital. In turn, finance relies upon at the earnings 
generated alongside the deliver chain. The coins flow monetary actors anticipate in go back for his or her investments in efficient and/or logistical enterprise ventures can most effective be found out via way of means of distinctive feature of the cloth flows of products alongside the deliver chain. Another critical conjuncture among operations of capital in finance and logistics is that monetary markets have end up so critical due to the fact they are alleged to characteristic as a safety mechanism to hedge the dangers concerned in global trade (Lee \& LiPuma, 2004). Financial derivatives permit globally working groups to hedge their transactions, in most cases in opposition to trade charge fluctuations, whilst they offer a supply for speculative income for investors like hedge funds (Lee \& LiPuma, 2004), pp. 67-83; (MacKenzie, 2008), 144ff.).

\section{METHODS}

In this article, the approach used is an evaluation of the prevailing literature research on monetary generation used withinside the discipline of logistics, and the belief is to make studies fabric or the following variable.

\section{RESULT AND DISCUSSION}

From numerous descriptions starting from creation to literature critiques on monetary generation withinside the discipline of logistics at this time, the primary has been utilized by a small variety of current logistics businesses, with numerous troubles which have been defined withinside the creation, wherein purchasers have now no longer maintained the confidentiality of the usage of monetary packages. generation utilized by logistics businesses each in supporting bills or packages for distribution to purchasers.

Second, concerning rules that enhance the monetary generation used withinside the logistics zone exists already and must stay monitored through the authorities in order that there are not a few fictitious monetary generations, lots of which might be most effective a cowl for fraud. There is an overarching law concerning this monetary generation, specifically the Financial Services Authority (OJK) Regulation Number 77 / PJOK.01 / 2016 regarding Technology-Based Money Lending and Borrowing offerings except that there are guidelines issued through Bank Indonesia with Bank Indonesia Regulation (PBI) No.19 / 12 / PBI / 2017 regarding the Implementation of Financial Technology and its Implementation Terms withinside the Regulation of Members of the Board of Governors (PADG) No.19 / 14 / PADG / 2017 regarding Limited Trial Space (Regulatory Sandbox).

More approximately this supply textual content Source textual content is wanted to gain extra translation statistics Financial Technology and PADG No.19 / 15 / PADG / 2016 concerning registration procedures, statistics submission, and Monitoring the Implementation of Financial Technology.

Third, there are not many Logistics Companies presently the usage of Financial Technology in helping monetary transactions for clients who use the offerings of logistic companies. The employer control has now no longer but used monetary generation and has help from the government, possibly withinside the shape of cooperation with monetary generation provider providers.

\section{CONCLUSION AND RECOMMENDATION}

Of the 3 descriptions withinside the consequences and dialogue above, there are 3 variables which can make destiny studies substances or references, particularly financial era that has been used with purchaser confidentiality this is nevertheless now no longer maximally maintained, secondly there may be a central authority coverage that surely covers this economic era in order that it may be used. supervised through the government.

Third, there are not many logistics businesses that use economic generation as a method of price to consumers, there are numerous obstacles, particularly from control choices and help that can be facilitated with the aid of using the authorities with the life of present Financial Technology Institutions with cooperation.

This qualitative study remains a way from perfect, and handiest as an overview fabric from researchers and as a contribution to the improvement of science, mainly withinside the subject of virtual finance, and logistics in general. 


\section{REFERENCES}

Allen, R., \& Garlan, D. (1997). A formal basis for architectural connection. ACM Transactions on Software Engineering and Methodology (TOSEM), 6(3), 213-249.

Awrey, D. (2013). Toward a supply-side theory of financial innovation. Journal of Comparative Economics, 41(2), 401-419.

Beck, U. (2002). Risk society: Towards a new modernity (S. Cieśla, Trans.). Warszawa: Wydawnictwo Naukowe SCHOLAR.

Bernanke, B. S., \& others. (2009). Financial innovation and consumer protection: a speech at the Federal Reserve System's Sixth Biennial Community Affairs Research Conference, Washington, DC, April 17, 2009.

Bielawski, J. (1971). Ultrastructure and ion transport in gill epithelium of the crayfish, Astacus leptodactylus Esch. Protoplasma, 73(2), 177-190.

Board, F. S. (2017a). Financial stability implications from fintech: Supervisory and regulatory issues that merit authorities' attention. June, Basel.

Board, F. S. (2017b). Fintech Credit, market structure, business models and financial stability implications. Committee on Global Financial System.

Collier, S. J., \& Lakoff, A. (2015). Vital systems security: Reflexive biopolitics and the government of emergency. Theory, Culture I\& Society, 32(2), 19-51.

Cowen, D. (2010). A geography of logistics: Market authority and the security of supply chains. Annals of the Association of American Geographers, 100(3), 600-620.

Cowen, D. (2014). The deadly life of logistics: Mapping violence in global trade. U of Minnesota Press.

Damuri, Y. R., Fauri, A., \& Rafitrandi, D. (2021). Perkembangan dan Regulasi E-commerce di Indonesia. 2020, $1-8$.

Danyluk, M. (2018). Capital's logistical fix: Accumulation, globalization, and the survival of capitalism. Environment and Planning D: Society and Space, 36(4), 630-647.

De Haan, J., Schoenmaker, D., \& Wierts, P. (2020). Financial markets and institutions: A European perspective. Cambridge University Press.

Folkers, A., \& Stenmanns, J. (2019). Logistical resistance against operations of capital: Security and protest in supply chains and finance. Geoforum, 100, 199-208.

Fontes, T., Costa, V., Ferreira, M. C., Shengxiao, L., Zhao, P., \& Dias, T. G. (2017). Mobile payments adoption in public transport. Transportation Research Procedia, 24, 410-417.

Gandara, G. (2018). Sruktur Organisasi Pada Sebuah Kantor Perwakilan Perusahaan Layanan Konten Video Pendek Berbasis Aaplikasi Bergerak. Tugas Pengganti Ujian Akhir Semester, IPB.

Hadzhieva, E. (2019). Impact of Digitalisation on International Tax Matters: Challenges and Remedies. European Parliament.

Holmes, T. J. (2011). The diffusion of Wal-Mart and economies of density. Econometrica, 79(1), 253-302.

Kreher, M., Sellhorn, T., \& Hess, T. (2017). Digitilization in accounting: Study of the Status Quo in German Companies.

Lee, B., \& LiPuma, E. (2004). Financial derivatives and the globalization of risk. Duke University Press.

Lehmacher, W. (2015). Globale Supply Chain: Technischer Fortschritt, Transformation und Circular Economy. Springer-Verlag.

Li, K., Kim, D. J., Lang, K. R., Kauffman, R. J., \& Naldi, M. (2020). How should we understand the digital economy in Asia? Critical assessment and research agenda. Electronic Commerce Research and Applications, 44, 101004.

MacKenzie, D. (2008). An engine, not a camera: How financial models shape markets. Mit Press.

Mao, X.-B., Wu, M., Dong, J.-Y., Wan, S.-P., \& Jin, Z. (2019). A new method for probabilistic linguistic multiattribute group decision making: Application to the selection of financial technologies. Applied Soft Computing, 77, 155-175.

Marx, K. (1963). Karl Marx: Early writings.(TB Bottomore, Ed. \\& Trans) New York. NY: McGraw-Hill.

Maulana, I. N. Y. (2018). Payung Hukum Perdagangan Elektronik (E-Commerce) dalam Tata Hukum Indonesia.[Ref November 16, 2018$].$

Meyer, J. P., \& Allen, N. J. (1997). Commitment in the workplace: Theory, research, and application. Sage publications.

Opitz, S., \& Tellmann, U. (2012). Global territories: Zones of economic and legal dis/connectivity. Distinktion: 
Scandinavian Journal of Social Theory, 13(3), 261-282.

Ozili, P. K., \& Outa, E. (2017). Bank loan loss provisions research: A review. Borsa Istanbul Review, 17(3), $144-163$.

Patel, K., \& McCarthy, M. P. (2000). Digital transformation: the essentials of e-business leadership. Language, $10(134 \mathrm{p}), 23 \mathrm{~cm}$.

Rahayu, E. A., Waluja, S. B., \& Sugiman, S. (2014). Keefektifan Model Arias Berbantuan Kartu Masalah Untuk Meningkatkan Kemampuan Komunikasi Matematis Siswa. Kreano, Jurnal Matematika KreatifInovatif, 5(1), 10-17.

Salter, M. B. (2013). To make move and let stop: Mobility and the assemblage of circulation. Mobilities, 8(1), $7-19$.

Supardianto, S., Ferdiana, R., \& Sulistyo, S. (2019). The Role of Information Technology Usage on Startup Financial Management and Taxation. Procedia Computer Science, 161, 1308-1315. https://doi.org/10.1016/j.procs.2019.11.246

Susilo, A. Z., Prabowo, M. I., Taman, A., Pustikaningsih, A., \& Samlawi, A. (2019). A comparative study of factors affecting user acceptance of go-pay and OVo as a feature of Fintech application. Procedia Computer Science, 161, 876-884.

Toppen, R., Smits, M., \& Ribbers, P. (1998). Financial securities transactions: a study of logistic process performance improvements. Proceedings of the Thirty-First Hawaii International Conference on System Sciences, 6, 582-591.

Tsing, A. (2009). Supply chains and the human condition. Rethinking Marxism, 21(2), 148-176.

Tsing, A. (2016). What is emerging? Supply chains and the remaking of Asia. The Professional Geographer, $68(2), 330-337$.

Vitasek, K. (2013). Council of Supply Chain Management Professionals.(2013). Supply Chain Management Terms and Glossary. En Supply Chain Management Terms and Glossary, 222. 